\title{
Educational Materials from the U.S. Geological Survey
}

\section{Introduction}

The U.S. Geological Survey (USGS) collects, analyzes, and publishes information about the Nation's mineral, land, biological, and water resources. Some of this earth science information is available as educational material in a variety of booklets, posters, fact sheets, and CD-ROM's. Described below are some products you may want to use.

Unless otherwise noted, all of the following publications are available from:

USGS Information Services

Box 25286

Denver, CO 80225

Fax: 303-202-4693

Orders for sales items are accepted by fax (303-202-4188) with a Visa or MasterCard. Please include a $\$ 3.50$ handling fee with any cost item. Please also include the ordering identification number that follows each publication description.

When applicable, World Wide Web addresses are given for those publications that can be downloaded.

Customers with access to fax machines or to personal computers with fax reception software can retrieve many of the publications by using the USGS Faxon-Demand System. To access the system, users can call from a fax machine's handset or from a touch tone telephone. Dial 703-648-4888 and press "2" on your telephone keypad for maps and publications information. Then after selecting " 2 " again, you can key in the EARTHFAX number of the

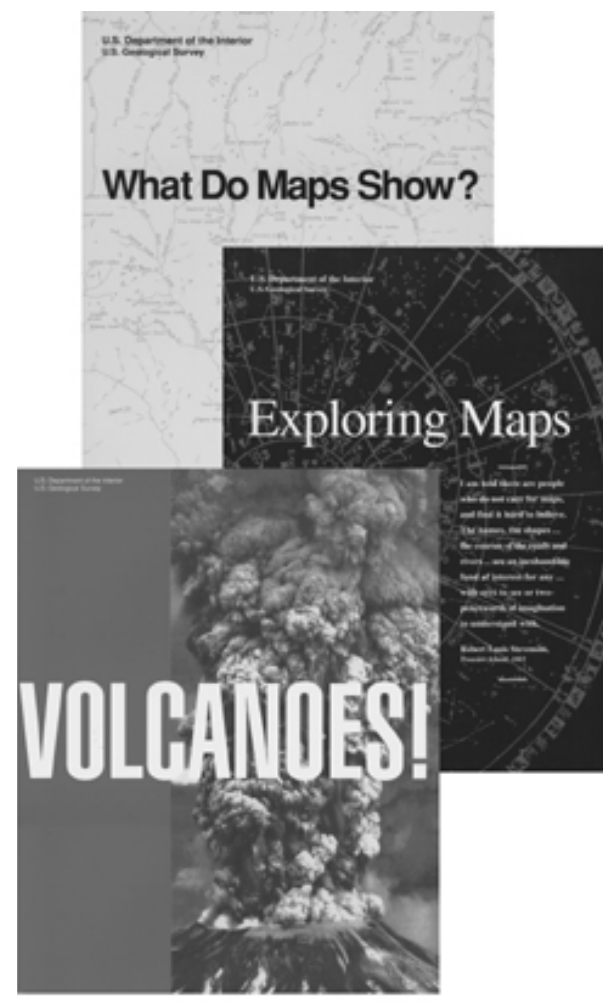

publication you want. You can request up to three documents per phone call.

Some publications are currently out of print. They may still be available through the Web or EARTHFAX. Such publications will be noted as "Web Only" or "EARTHFAX Only."

\section{Teaching Packets with Activities}

Request the following teaching material on school letterhead.

Exploring Caves--This K-3 teaching packet covers the related subjects of geology, cartography, and hydrology in a lighthearted story of Bat who finds two lost children in a cave and teaches them various lessons as he guides them to safety. The packet includes a large, colorful poster, an instructional book for teachers that contains the read-aloud story, lesson plans, and student activity sheets. 97-0400

Map Adventures-This packet is appropriate for grades K-3. Students will learn basic concepts for visualizing objects from different perspectives and how to understand and use maps. Includes a two-sided color poster, teacher information, seven lesson plans, and two activity sheets. 97-0300 <URL: http://www.usgs.gov/education/ learnweb/MA/>

What Do Maps Show?-Includes a twosided color poster with four accompanying lessons for geography and map reading appropriate for upper elementary to junior high school. Also includes three reproducible maps and four reproducible activity sheets. 97-0250 <URL: http://www.usgs.gov/education/ teacher/what-do-maps-show/index.html>

Global Change-This packet is appropriate for grades 4-6. It covers four themes: time, change, natural cycles, and the Earth as home. Includes a two-sided color poster, teacher guide, and three activities. Each activity includes background material, an experiment, three lesson plans, and suggestions for further reading. 97-0200

<URL: http://www.usgs.gov/education/ learnweb/GC.html>

Volcanoes-This teaching packet for grades 4-8 will answer fundamental questions about volcanoes through the story of the 1980 eruption of Mount St. Helens. Includes a two-sided color poster, a teaching guide with glossary and bibliography, and six lesson plans 
with timed activities and reproducible sheets. 97-0995

Exploring Maps-An interdisciplinary set of materials on mapping for grades 7-12 designed to aid in teaching basic mapmaking and map-reading skills. Includes a teaching guide, four activity sheets, and two double-sided posters. 97-0150

<URL: http://www.usgs.gov/education/ learnweb/Maps.html>

\section{Paper Models}

The following reports are threedimensional, cut-and-paste paper models and computer animations illustrating geologic processes and other geological phenomena. Both paper copies and electronic versions are available. Both versions have the same patterns and text, although the electronic version may have animations that describe geologic processes. The electronic versions require an Apple computer with a $1.4 \mathrm{Mb}$ disk drive, a hard drive, Hypercard 2.0, and generic word processing and graphics programs. Many of the model animations are available to view on the World Wide Web at <URL: http://www.usgs.gov/ education/animations/>.

How to Construct Two Paper Models Showing the Effects of Glacial Ice on a Mountain Valley-Two models showing a mountain valley partly filled by a glacier and the same valley after the glacier has melted.

OF 89-190 A, paper copy, 20 p. $\$ 3.00$

OF 89-190 B, 3.5-inch diskette $\$ 10.00$

<URL: http://www.usgs.gov/education/ learnweb/ice.html>

How to Construct a Paper Model Showing the Motion That Occurred on the San Andreas Fault During the Loma Prieta, California, Earthquake of October 17, 1989-Contains instructions and patterns for preparing a threedimensional model that schematically illustrates the fault motion that occurred during the earthquake.
OF 89-640 A, paper copy, 10 p. $\$ 1.50$

OF 89-640 B, 3.5-inch diskette $\$ 10.00$

How to Construct Seven Paper Models That Describe Faulting of the EarthThese are paper patterns describing normal, reverse, right- and left-lateral strike-slip, and oblique-slip faults, and models of two fault-produced landforms, a graben and a horst.

OF 90-257 A, paper copy, 42 p. $\$ 6.25$

OF 90-257 B, 3.5-inch diskette $\$ 10.00$

Make Your Own Paper Model of a Volcano-Description of and pattern for making a paper model showing the inside and outside of a stratovolcano.

OF 91-115 A, paper copy, 4 p. $\$ 1.50$

OF 91-115 B, 3.5-inch diskette $\$ 10.00$

<URL: http://www.usgs.gov/education/ learnweb/volcano.html>

EARTHFAX: 7211

How to Construct Four Paper Models That Describe Coral Reefs-Description and four paper models describing island reefs. The first model is a shield volcano that extends above the sea level, the second is a volcano with a fringing reef of coral, the third is a volcano with a coral reef and a lagoon, and the fourth is an atoll.

OF 91-131 A, paper copy, 20 p. $\$ 3.00$

OF 91-131 B, 3.5-inch diskette $\$ 10.00$

Map Projections-Describes and illustrates four main types of map projections commonly used to present thematic data.

OF 91-553 A, paper copy, 92 p. $\$ 14.00$

OF 91-553-B, 3.5-inch diskette $\$ 10.00$

Earthquake Effects --A Computer

Animation and Paper Model-Illustrates by paper model and computer animation how an earthquake occurs and what types of damage may result.

OF 92-200 A, paper copy, 22 p. $\$ 3.50$

OF 92-200 B, 3.5-inch diskette $\$ 10.00$

Landslide Effects-Description, paper models, and animations of four kinds of landslides: slump, slide, flow, and fall.
OF 93-278 A, paper copy, 43 p. $\$ 6.50$ OF 93-278 B, 3.5-inch diskette $\$ 10.00$

Make Your Own Earth and Tectonic Globes-This report contains instructions and two patterns for making a terrestrial globe and a tectonic globe that are glued onto a tennis ball.

OF 93-380 A, paper copy, 14 p. $\$ 2.25$

OF 93-380 B, 3.5-inch diskette $\$ 10.00$

Northridge, California, Earthquake of January 1994-This report contains animations and a paper model of the Northridge, California, earthquake.

OF 94-214 A, paper copy, 30 p. $\$ 4.50$

OF 94-214 B, 3.5-inch diskette $\$ 10.00$

Make Your Own Paper Fossils_-This report contains animations and paper models of two fossils.

OF 94-667 A, paper copy, 42 p. $\$ 6.50$

OF 94-667 B, 3.5-inch diskette $\$ 10.00$

Sea-Floor Spreading-A Computer Animation and Paper Model-Distributed with a Macintosh-compatible 3.5-inch diskette along with the paper copy.

OF 95-573 $\$ 15.25$

Arctic Delta Processes-This report shows, by means of a computer animation and paper models, how deltas are affected by fresh and salt water currents, topography, and location. It is intended to help students visualize how ice shapes and forms a delta.

OF 95-843 A, paper copy, 27 p. $\$ 4.25$

OF 95-843 B, 3.5-inch diskette $\$ 10.00$

Ocean Trenches-This report contains computer animations and a paper model illustrating how a subduction zone works. Students will better understand the processes that operate at converging margins between tectonic plates and how ocean trenches and the volcanoes associated with them are developed.

OF 96-76 A, paper copy, 41 p. $\$ 6.25$

OF 96-76 B, 3.5-inch diskette $\$ 10.00$ 
Crinoids-This report shows, through computer animations and a paper model, how crinoids lived and became fossilized.

OF 97-91 A, paper copy, 56 p. $\$ 9.00$ OF 97-91B, 3.5-inch diskette $\$ 10.00$

Chicxulub Impact Event-This report contains two paper models and computer animations that help illustrate how dinosaurs may have become extinct as a result of an asteroid impact.

OF 97-442 A, paper copy, 36 p. $\$ 5.50$ OF 97-442 B, 3.5-inch diskette $\$ 10.00$

Karst Topography-This report illustrates, through computer animations and a paper model, why caves develop in limestone. By studying the animations and the paper model, students will better understand the evolution of Karst topography.

OF $97-536$ A, paper copy, 36 p. $\$ 9.00$

OF 97-536 B, 3.5-inch diskette $\$ 10.00$

\section{Posters}

Map Projections-This two-sided poster shows the frontispiece to Gerardus Mercator's Atlas sive Cosmographicae on one side and properties, characteristics, and preferred uses of many historically important projections and of those frequently used today on the reverse side.

96-0200 (flat version)

96-0201 (folded version)

Fossils Through Time-A poster depicting the diversity and evolution of life on Earth during the last 600 million years, with photographs of fossils and corresponding explanations. 96-0100

Planetary Maps --A two-sided poster showing a part of a geologic map of the near side of the Moon on one side and, on the other side, the variety of maps available of the Moon and Mars and some of Earth's other neighboring planets and their satellites.

96-0275 (folded version)

This Dynamic Planet-A world map of volcanoes, earthquakes, and plate tectonics. Complements This Dynamic

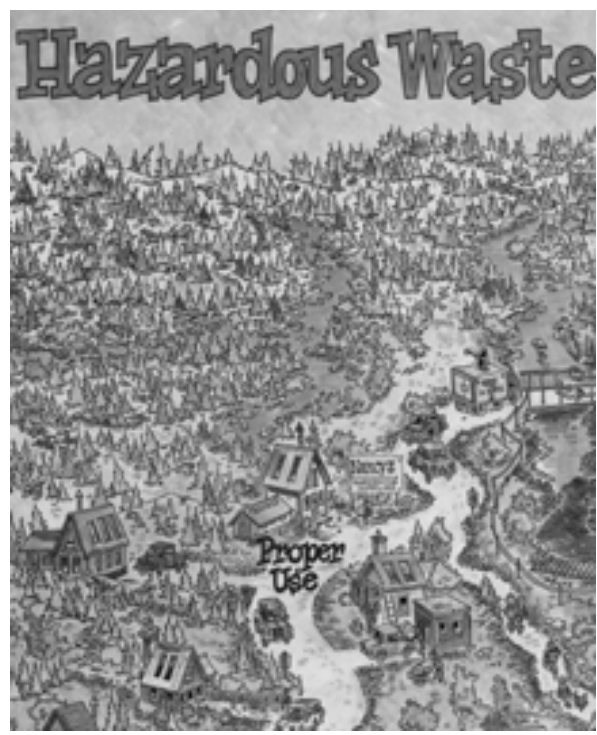

Earth: The Story of Plate Tectonics

booklet. $\$ 4.00$

GIA0023T (flat version)

GIA0022D (folded version)

Landforms of the Conterminous United

States - A Digital Shaded-Relief

Portrayal-A large, digitally produced map illustrating geomorphic and tectonic phenomena of the United States in vivid detail. A16-page booklet describing the map accompanies it. \$4.00 GI2206-1T

Digital Shaded-Relief Image of AlaskaA large map illustrating the physiographic features of Alaska from artificial rendering of a digital elevation model.

An 11-page booklet describing the map accompanies it. \$4.00 GI2585-1T

Mapping the Solar System-A twosided poster with colorful airbrush illustrations of the planets and their satellites on one side and statistical information and geographic feature information on the reverse side. $\$ 4.00$ GI $2447 \mathrm{~T}$

Geology of the Solar System-A twosided poster with colorful geologic mapping and low-resolution shadedrelief airbrush mapping of the Terrestrial Planets and Outer Satellites shown on one side and textural geologic information given on the reverse side. $\$ 4.00$ GI 2596T

Each poster listed below is available in two versions - grade school or middle school. The posters have activities, definitions, discussions, and interpretive questions. The front side of each poster has a colorful cartoon graphic. The level of educational material on the back is different for grade and middle school. The posters can be joined to create a wall mural.

<URL: http://water.usgs.gov/public/ outreach/OutReach.html>

Water: The Resource That Gets Used and Used and Used For Everything!-

Depicts 12 uses of water, from mining to transportation. Shows the flow of water from the mountains through a reservoir, and past urban, rural, and industrial settings where various uses are shown. This poster is also available in Spanish.

96-0461 (grade school)

96-0462 (middle school)

96-0460 (black-and-white version)

How Do We Treat our Wastewater?Depicts the process by which wastewater is treated in cities, small towns, and rural areas.

96-0464 (grade school)

96-0465 (middle school)

Wetlands: Water, Wildlife, Plants, and People!-Shows general types of wetlands and demonstrates how wetlands are beneficial. The diversity of plants and animals in wetlands is also shown.

96-0467 (grade school)

96-0468 (middle school)

Ground Water: The Hidden Resource!Displays the movement of water in a ground water system.

96-0458 (grade school)

96-459 (middle school)

Water Quality ... Potential Sources of Pollution-Displays human activities associated with different sources of water pollution. Also shows the movement of waters between surface and ground water systems.

96-0469 (grade school)

96-0470 (middle school)

Navigation: Traveling the Water Highways!-Highlights different kinds of vessels, port facilities, structures, and equipment needed for commercial 
operations on rivers and in coastal harbors. It is designed to introduce students to the many aspects of navigation.

96-0473 (grade school)

96-0474 (middle school)

Hazardous Waste: Clean-Up and Prevention-Depicts various hazardous waste sites, different types of cleanup methods used on these sites, and how hazardous waste moves once it is released in the environment.

96-0476 (grade school) 96-0477 (middle school)

96-0475 (black-and-white version)

Watersheds: Where We Live-This poster depicts three watersheds, identifying different physical features and management options within each watershed. The poster also depicts flooding and the importance of flood plains.

96-0479 (grade school)

96-0480 (middle school)

96-0478 (black-and-white version)

Oceans-Coastal Hazards: Hurricanes, Tsunamis, Coastal Erosion-As a contribution to the Year of the Ocean, 1998, this poster was designed to describe several natural processes or events that can change the shape of the coast and affect nearby environments.

96-454 (grade school)

96-455 (middle school)

96-453 (black-and-white version)

\section{Booklets}

Helping Your Child Learn GeographyThis 32-page booklet, published in cooperation with the U.S. Department of Education and the National Geographic Society, is designed to help parents stir children's curiosity about geography. The activities can also be used in the classroom. The activities are designed for children 5-10 years of age.

94-0130

<URL: http://www.ed.gov/pubs/parents/ Geography/index.html>

Fossils, Rocks, and Time-This 24-page

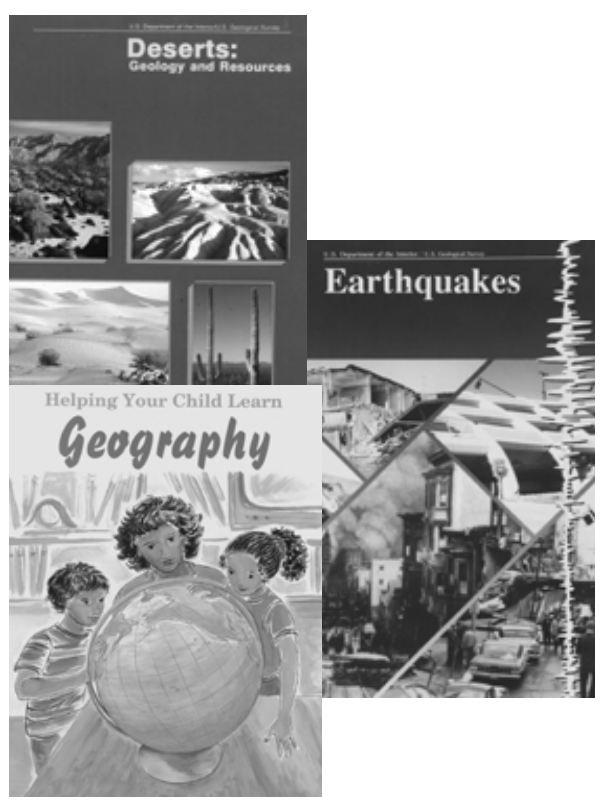

booklet explains the basics of how fossils are used in establishing time sequence in geology. Accompanies the poster,

Fossils Through Time. 94-0054

<URL: http://pubs.usgs.gov/gip/fossils/> Web Only

The Geology of Radon-This 28-page booklet presents geological information about radon, including how it forms, the kinds of rocks and soils it comes from, and how it moves through the ground or is carried by water. Geologists also explain in the booklet how they estimate the radon potential of an area. 94-0115 <URL: http://sedwww.cr.usgs.gov:8080/ radon/georadon.html/>

Deserts: Geology and Resources-This 60-page booklet describes various types of deserts, including extraterrestrial deserts, illustrates various desert features and eolian (wind) processes, and discusses the use of remote sensing in studying deserts and the process of desertification. 94-0041

<URL: http://pubs.usgs.gov/gip/deserts/> Web Only

Elevations and Distances-This 15-page booklet provides tables of information covering elevations of features and distance between points in the United States. 93-0090

Earthquakes-This 20-page booklet explains the nature and causes of earthquakes. Describes techniques used to detect, record, measure, and predict seismic disturbances. 94-0050

<URL: http://pubs.usgs.gov/gip/ earthq1/>

Acid Rain and Our Nation's Capital: A Guide to Effects on Buildings and Monuments-This 35-page booklet focuses on acid rain and its impact on our Nation's capital. The booklet defines acid rain, explains what effects it has on marble and limestone buildings, and shows, through a walking tour, some of the places in our Nation's capital where you can see the impact of acid precipitation. 94-0051

<URL:http://pubs.usgs.gov/gip/acidrain/>

Volcanoes-This 45-page booklet presents a summary of the nature of the Earth processes that create common types of volcanoes around the world, along with an introduction to the techniques of volcano monitoring research. 94-0195

<URL: http://pubs.usgs.gov/gip/volc/> Web Only

Volcanoes of the United States-This 44page booklet describes the principal volcanoes in Hawaii, Alaska, and the Cascades Mountain Range that have erupted during the last few hundred years. Also summarizes recent events at active calderas in California and Wyoming. 93-0610

<URL:http://pubs.usgs.gov/gip/volcus/> Web Only

Geologic Time-This 20-page booklet explains relative and radiometric time scales and how geologists measure the age of the Earth. Illustrates the scientific processes that are used to interpret the Earth's geologic history. 94-0121 <URL:http://pubs.usgs.gov/gip/geotime/> Web Only

Topographic Mapping-This 20-page booklet introduces the elements of topographic mapping, including principal map series, scale, control surveys, national standards, procedures, symbols, revisions, and digital mapping. 94-0190

USGS Maps-This 28-page booklet illustrates and describes types of USGS maps and gives ordering information. 93-0581 
Aerial Photographs and Satellite Images-This 21-page booklet illustrates various USGS aerial photographs and remotely sensed products. 96-0011

This Dynamic Earth: The Story of Plate Tectonics-This colorfully illustrated 77page booklet complements the This Dynamic Planet poster and describes in detail the various aspects of plate tectonics. \$6.00 92-TDE

<URL:http://pubs.usgs.gov/publications/ text/dynamic.html>

Eruptions of Mount St. Helens: Past, Present, and Future-This 56-page booklet highlights the eruptive history of this composite volcano, reviews its activity since its awakening in 1980, and speculates about its behavior in the future. \$3.75 92-MTSTH

<URL: http://pubs.usgs.gov/publications/ $\mathrm{msh} />$

Eruptions of Hawaiian Volcanoes: Past, Present, and Future-This 54-page booklet focuses on the volcanic history of the Hawaiian Islands with dramatic color photographs and diagrams and informative text on Hawaii's active shield volcanoes, Mauna Loa and Kilauea.

\$4.00 92-HAWV

<URL: http://pubs.usgs.gov/gip/hawaii/>

Natural Gemstones-This 16-page booklet describes mineral and organic gemstones. Values of U.S. production of natural and synthetic minerals versus imports are given, as well as gemstone chemical formulas. Selected references are also supplied.

<URL: http://pubs.usgs.gov/gip/ gemstones/>

Web Only

The San Andreas Fault-This 17-page booklet defines the San Andreas Fault. Earthquake magnitude and intensity are also discussed.

<URL: http://pubs.usgs.gov/gip/earthq3/> Web Only

Dinosaurs: Facts and Fiction-This 10page leaflet answers a series of basic questions on dinosaurs, such as "Where did dinosaurs live?" and "Why did dinosaurs grow so big?" References are

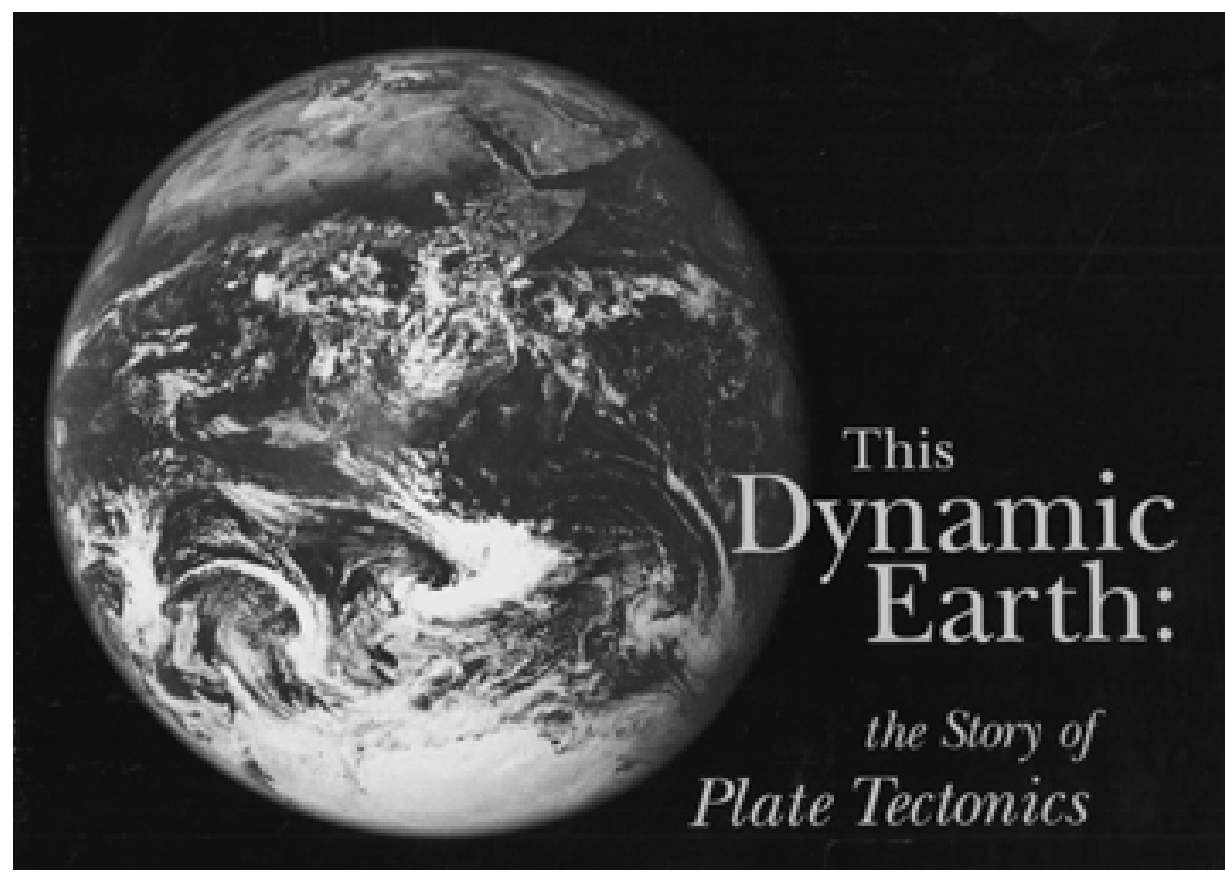

also included.

<URL: http://pubs.usgs.gov/gip/ dinosaurs/>

Web Only

Ground Water and the Rural

Homeowner-This 36-page booklet provides the rural homeowner with a basic description of ground water and problems one may expect to encounter when building, such as contamination from septic systems and lowered wellwater levels. 94-0055

\section{Fact Sheets}

Earth Science Information SourcesLists address, telephone numbers, and e-mail addresses for sources of mapping, geologic, water, and biological resources information from the USGS. FS-125-95 <URL: http://mapping.usgs.gov/mac/isb/ pubs/factsheets/fs12595.pdf> EARTHFAX: 3001

Drought-This fact sheet provides information on what droughts are, where they usually occur in the United States, and what can be done to solve water problems during periods of drought. FS-93-642 EARTHFAX: 5502

Floods and Flood Plains-Describes flood plains, factors that influence when or where floods occur, and how flood damage can be reduced. FS-93-641
EARTHFAX: 5503

USGS Tracks Acid Rain-Explains what acid rain is, how it is formed, and what its effects are, and also gives some information on what can be done to help control acid rain. FS-183-95

<URL: http://BTDQS.usgs.gov/jgordon/ arfs.html>

EARTHFAX: 5504

Earth Science Publications Fact SheetsGives descriptions for many of the fact sheets available from the USGS National Mapping Division. FS-120-96

<URL: http://mapping.usgs.gov/mac/isb/ pubs/factsheets/fs 12096.pdf>

EARTHFAX: 3028

What is Ground Water?-Explains how water gets into the ground. Associated terms such as water table, aquifer, permeability, and porosity are illustrated and explained. FS-93-643

EARTHFAX: 5501

Selected Earth Science Publications Booklets, Leaflets, and Posters-Gives descriptions and ordering information for USGS National Mapping Division booklets, leaflets, and posters.

FS-100-96 EARTHFAX: 3027

How to Obtain Aerial PhotographsIncludes general information on ordering aerial photographs from the USGS and a checklist. FS-140-97 
National Atlas Maps-Aselection of maps originally published in the National Atlas of the United States of America by the USGS in 1970. FS-245-95

<URL: http://mapping.usgs.gov/mac/isb/ pubs/factsheets/fs24595.pdf $>$

Map Scales_Explains map scales and includes a table comparing the scales of various USGS map series. FS-97-334 EARTHFAX: 3103

U.S. Geological Survey World Wide Web Information-A selection of USGS World Wide Web sites that offer information on scientific research and monitoring programs conducted in the areas of natural hazards, environmental resources, and cartography. FS-121-96 <URL:http://mapping.usgs.gov/mac/ isb/pubs/factsheets/fs12196.pdf>

EARTHFAX: 3017

Web and EARTHFAX Only

Looking for an Old Aerial PhotographLists sources for obtaining historical aerial photographs, including the USGS, the National Archives and Records Administration, and the Library of Congress. FS-127-96

<URL: http://mapping.usgs.gov/mac/isb/ pubs/factsheets/fs12796.pdf>

EARTHFAX: 3204

Looking for an Old Map-Lists uses of historical maps and sources, including the National Archives, the USGS, and the Library of Congress. FS-024-94

EARTHFAX: 3118

EARTHFAX Only

Map Projection Publications-Describes nine USGS publications about map projections. FS-081-97

EARTHFAX: 3112

\section{World Wide Web Site Information Sources}

The following USGS World Wide Web sites will direct you to additional educational source material.

<URL: http://www.usgs.gov/education/> -USGS Learning Web Site. This site points to a variety of resources for the K-12 and life-long learning audiences.

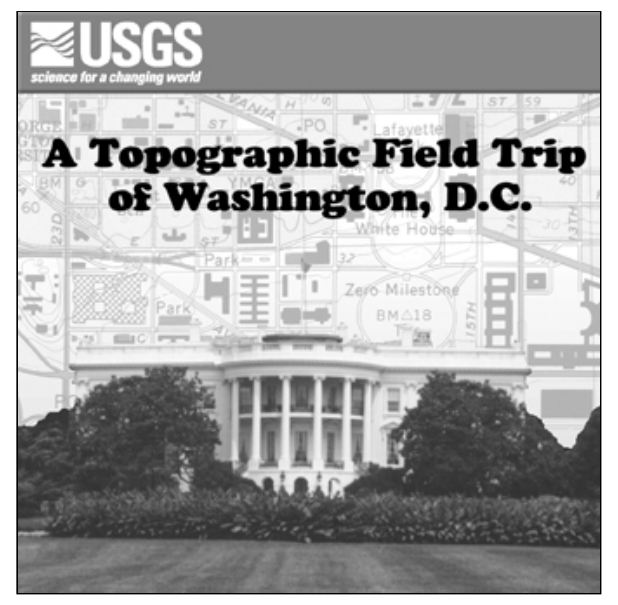

and direction, determine latitude and longitude, identify map features, understand digital orthophotos, determine elevations, and examine historical maps. 01-WASHDC_-Macintosh ${ }^{\circledR}$ version free while supply lasts 01-WASHDC2-Macintosh® and Windows $® 3.1 x$ or $95 \$ 11.50$

The following CD-ROM can be requested from USGS Information Services or the following address:

InterNetwork Media, Inc. 411 Seventh St.

It focuses on living, learning, and exploring the web of life.

<URL: http://www.mesc.nbs.gov/ butterfly.html> —Children's Butterfly Site. This site was developed for grades 4-6. Information is given on moths and butterflies, along with a coloring page, frequently asked questions and answers, a gallery of butterfly photographs, and links to other sites.

<URL: http://www.nwrc.gov>-USGS National Wetlands Research Center Site. Within this site you can click on "Education" to find The Fragile Fringe: A Guide for Teaching About Coastal Wetlands teacher guide. An introduction is given on wetlands, along with several activities and additional resource lists.

<URL: http://www.npwrc.org/resource/ othrdata/westflor/westflor.htm >Northern Prairie Wildlife Research Center, Western Wetland Flora, Field Office Guide to Plant Species Site. This site gives information on 300 species of vascular plants, including an illustrated glossary of floral terms and a species list and identification key.

\section{CD-ROM's}

Topographic Field Trip of Washington, D.C.-Designed for middle school students to travel through Washington, D.C. Uses hypermedia to navigate through layers of information and link sounds, graphics, text, animation, and interactivity in a game-like adventure. Students will learn to measure distance
Del Mar, CA 92014-3013

Phone: 888-755-3041

Fax: 619-481-8181

E-mail: inm@in-media.com

GeoMedia-Designed to teach children ages 10-14 about earth science. Developed jointly by the USGS and InterNetwork Media, the program includes information in six areas: Understanding Maps, Time and Change, The Greenhouse Effect, the Carbon Cycle, Earthquakes, and the Water Cycle. GeoMedia, available for Windows ${ }^{\circledR}$ or Macintosh ${ }^{\circledR}$ platforms, can be used in a classroom setting or on your own. If ordering from the USGS Information Services, the cost is $\$ 39.95$ plus $\$ 3.50$ handling. If ordering from InterNetwork Media, the cost is $\$ 39.95$ plus $\$ 5.00$ shipping (plus tax for Calif. residents). 01-GEOMEDIA

\section{Information}

For information on these and other USGS products and services, call 1-800-USA-MAPS, or use the EARTHFAX fax-on-demand system, which is available 24 hours a day at 703-648-4888.

Please visit the USGS home page at <URL: http://www.usgs.gov/>.

Any use of trade, product, or firm names is for descriptive purposes only and does not imply endorsement by the U.S. Government. 